\title{
Light Control Design by Using Social Media Telegram Applications Based on Internet Of Things (IOT)
}

\author{
Rudi Arif Candra ${ }^{1}$ \\ Politeknik Aceh Selatan \\ Tapaktuan, Indonesia \\ Rudi_candra@poltas.ac.id \\ Hardisal $^{3}$ \\ Politeknik Aceh Selatan \\ Tapaktuan, Indonesia \\ hardisal@poltas.ac.id
}

\author{
Dirja Nur Ilham ${ }^{2}$ \\ Politeknik Aceh Selatan \\ Tapaktuan, Indonesia \\ dirja@poltas.ac.id \\ Sriwahyuni ${ }^{4}$ \\ Politeknik Aceh Selatan \\ Tapaktuan, Indonesia \\ Sriwahyuniblk94@gmail.com
}

\begin{abstract}
Internet of things (IoT) is a concept with the aim of expanding the connectivity of internet network connected to global networks. Internet of Things (IoT) is used to control electronic device that utilizes internet technology to perform control processes such as lamp. This study aims to build control device that utilizes internet technology to carry out the light control process by utilizing social media telegram applications. With NodeMCU V3 as a Digital controller that supports TCP / IP technology. The testing method is carried out using 4 lights and 4 channel relays. The results obtained by the testing process by using commands on the telegram have been successful, the delay time is very dependent on internet connectivity or Wifi.
\end{abstract}

Keywords : NodeMCU, TCP/IP, Delay, Wifi

\section{INTRODUCTON}

With the development of internet infrastructure today, we are starting to enter a new era where not only computers and smartphones will be connected to the internet, any objects around us have the potential to connect to the internet, objects that we previously knew were silent, will start moving, voice and interact. this concept is better known as the "Internet of Things". The Internet of Things is a network of devices that are connected to each other through the internet and communicate independently without human intervention. The three main components of IoT devices are sensors, connectivity and control. Control is needed to be able to capture a natural phenomenon, such as temperature, pressure, vibration, sound, light, and so on. Connectivity is needed so that the device can communicate with other devices, its relationship with storage and retrieval of data from monitoring control sensors to be a major part of IoT devices, in order to read sensor values, send and receive data from and store media, and conduct a series of responses based on data obtained . Currently smartphones have the ability to connect to the internet and on average are equipped with several sensors such as touch screens, light sensors, accelerometers, gyroscopes and compasses [1].

At the time this was a lot of android smartphone usage in the household appliance control method by utilizing the default bluetooth facility of the smartphone itself [2]. In addition the internet can also play a role in controlling household tools in particular controlling the lights as the research that has been conducted by Karomah by leveraging internet connections and websites [3].

In research conducted by Ellian dkk, controlling lamp test process using the arduino uno mikrokontroller through ESP8266 's too late to get data from thingspeak.com for 23 seconds it caused the application control light on Android is still using a third party application. On the research conducted by Dhenny R dkk (2017) controls the lights through the use of a single board Raspberry Pi and internet messaging, use Whatsapp as social media applications [3].

Based on the description above, the author intends to conduct research under the title "Light Control 
Design by Using Social Media Telegram Applications Based on Internet Of Things (IOT)".

\section{RESEARCH METHODOLOGY}

\section{Type Of Research}

This study uses experimental research methods because in its implementation includes system analysis and system design. This research is structured as an experimental research that is designing a series and testing a series that has been built with the aim to determine the system behavior factors for each component in the system that has been built.

The stages are as follows:

1. Determining the Problem

This stage is done to look for problems related to the use of NodeMCU V3

2. Literature Study

This stage is done to find information regarding systems that have been built using NodeMCU V3

3. Research Design

There are 2 parts in the fast design phase, namely:

a. Hardware Designing

Hardware design aims to design equipment / support circuits for the system to be created.

b. Software Designing

Software design is done to facilitate the making of software later.

4. Testing Tools

At this stage testing is carried out on a system that has been designed, whether it is running or not a system with a planned purpose.

5. System Analysis

At this stage an analysis of the system has been carried out by looking at the side to be measured.

6. Report Making

At this stage is conducting a research report that covers the results of system testing and analysis and ends with conclusions.

Maintaining the Integrity of the Specifications

\section{A. Research Instrument}

The instruments in this study are the tools and materials used in the research process. This research has materials consisting of hardware and software.

1. Hardware Requirements

2. Software Requirements

With the help of the fritzing application, a hardware design scheme is made as follows: The light bulb needed for the process is 4 pieces with a maximum power of 5 watts, each lamp is connected to a PLN 220 volt AC power, and connected to Normally open to positive and Normally Close to negative, while the input to the VCC NodeMCu source is connected to the relay, In 1 to the Digital input D1, In 2 to the digital input D2, In 3 to the input D5, In 4 on the digital input D6 and GND on GND

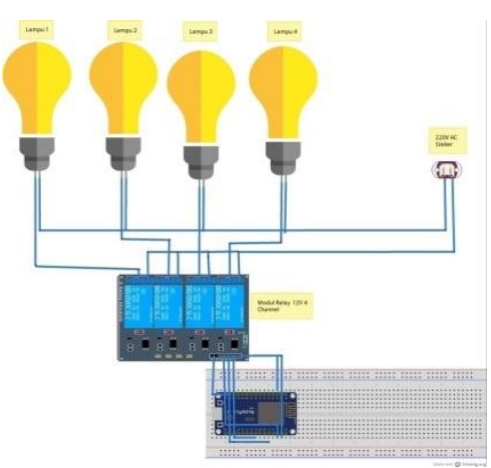

Figure 1. Light Control Schematic Design

The process of controlling and controlling the on / off lights using the NodeMCU V3 device as a Microcontroller that already supports and supports TCP / IP so that on one board the board can already run the remote control process. In order to be able to communicate in realtime (online) on both sides, the client side must be connected to the internet network either using data packets via smartphone or wifi media. The smartphone used is already installed the telegram media social application, which can be downloaded for free via playstore. On the side of the device to be controlled here using a 4 channel relay output in the form of lights with a total of 4 pieces, where the voltage source uses 220 Ac Current, the NodeMCU controller device must be connected to the internet network, so the two-way communication process can run

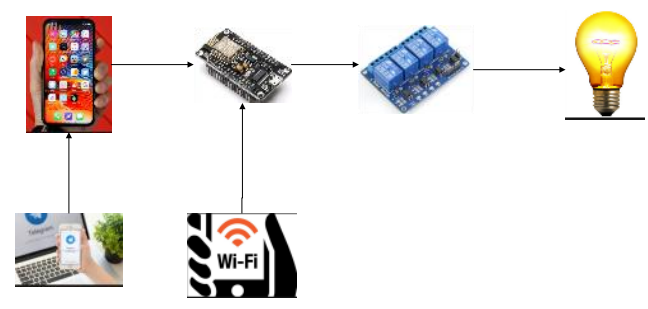

Figure 2. Lamp Control Diagram

The process of designing and writing coding uses Arduino Ide 1.8.5, and can be seen in Figure 3, below, the first process is to design communication with WIFI media, by entering the SSID and password. Next by inserting the telegram Token. Declaration of input to Relay, the next process is to declare the command / command that is used to turn on or turn off the light, 
the command for Control will be affected by small letters on the telegram.

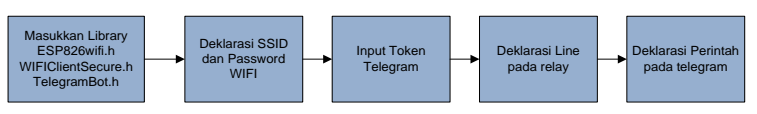

Figure 3. Software Design Scheme

\section{B. Designing Notifications Via Telegram}

Before using the Telegram application, Telegram Bot (Robot) is first prepared, its function is to facilitate the process of making chat or moderation applications within the Telegram itself. the first process is to install the Telegram Via Playstore application on an Android cellphone, in the search column type the command botfather or @ BotFather as shown in figure 4

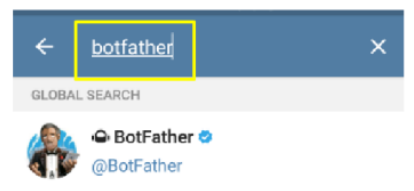

Figure 4. Bot Telegram

Next type start, and select / Newbot

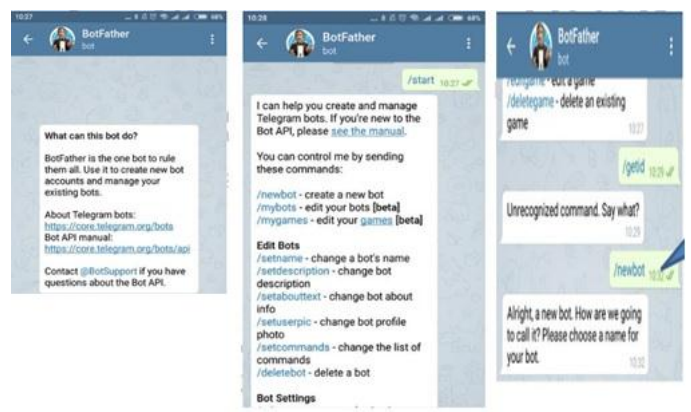

Figure 5. The process of creating a bot account

Create a name for Bot, each name added by the word Bot, here the author makes the name @ computerbot. The next process of telegram will send API tokens, this code aims to communicate with telegram via NodeMCU programming, as seen in figure 5 , so the process can run, by opening a browser and entering the address .

https://api.telegram.org/bot670004484:AAEZayZ7J1 HAudWOn3b2rsZrst0vcWSFuAU / getUpdates, and the results can be seen in Figure 6.

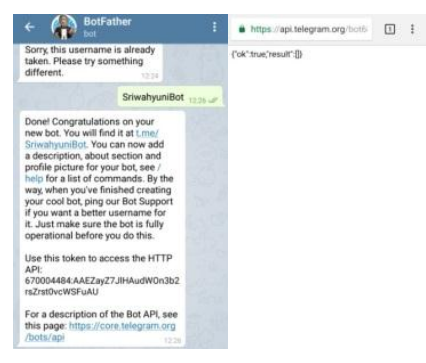

Figure 6. The Process of Checking a Telegram Token

\section{IMPLEMENTATION}

In accordance with the schematic that was planned in Chapter 3 using the fritzing application, the physical construction of components and tools was obtained, as shown in figure 7 as follows:

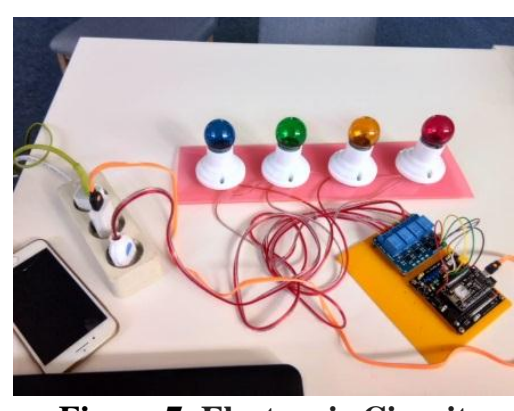

Figure 7. Electronic Circuit

From Figure 7 on the implementation of the needs of tools and device control to design lamps by using the telegram app, it takes 4 ( four ) lamp 5 watt, with size with electronics configuration pitting the lights were made by parallel in order to control bulb using digital. switching the relay asSo that the process on / off the lights seemed clear, a lamp shade made variegated, to the input on the relay 1 used red, the input relay 2 on light yellow color, the input relay 3 on light green color, and the input relay 4 on light blue.

The next process is to connect the device with the device using a jumper cable, the position between Nodemcu, and the relay can be seen in Table 1 , With the following components :

VCC 5volt voltage source on the relay is connected to the voltage source at NodeMCU VCC, GND Grounding position is connected with Grounding GND at NodeMCU, First Input IN1 Relay is connected to Digital Input D1 at NodeMCU, second input IN2 relay connected with digital input on D2 NodeMCU, third 
input IN3 on the relay is connected with Digital Input D5 at NodeMCU and the fourth Input to relay IN4 is connected to Digital Input in NodeMCU D6.

Table 1.Relay Module Connection with NodeMCU

\begin{tabular}{|c|c|}
\hline Relay & NodeMCU \\
\hline VCC & VCC \\
\hline GND & GND \\
\hline IN1 & D1 \\
\hline IN2 & D2 \\
\hline IN3 & D5 \\
\hline IN4 & D6 \\
\hline
\end{tabular}

\section{a. WIFI testing on the NodeMCU} Module

The first testing process is to test the NodeMCU device connection, as shown in figure 8. Existing NodeMCU devices already support TCP / IP Technology, which means the NodeMCu device has a wifi module. The process of testing a wifi device is to write on the program type or the name of the device access point (SSID), then write the password of the device. The next process is to set the serial monitor on the boundrate 115200 on the Arduino Ide
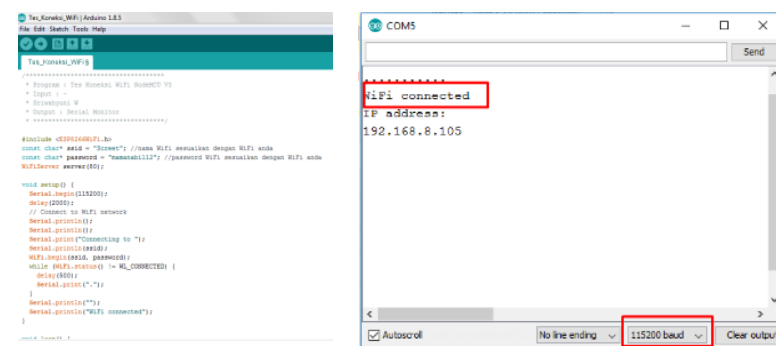

Figure 8. Wifi Testing Modul

Save and upload the program in NodeMCU, and open the serial monitor (Tools Serial monitor) wait until "wifi Connected" appears, as shown in figure 8.

\section{Testing Using Telegram}

The testing process by using telegram, which must be done is to enter the telegram Token and Telegram Id in the program that was created. For the process of running the application on the telegram note the size of the command or command, this affects the command on the control lights. In Table 2 the command is used to process the light control, to turn on lamp 1, type light 1 on the telegram page, while to turn off the light use command 1 off. Each command will be executed in sequence and one by one.

Table 2. Command Control

\begin{tabular}{|c|l|}
\hline Command & \multicolumn{1}{|c|}{ Control } \\
\hline 1 on & Lampu 1 ON \\
\hline 1 off & Lampu 1 OFF \\
\hline 2 on & Lampu 2 ON \\
\hline 2 off & Lampu 2 OFF \\
\hline 3 on & Lampu 3 ON \\
\hline 3 off & Lampu 3 OFF \\
\hline 4 on & Lampu 4 ON \\
\hline 4 off & Lampu 4 OFF \\
\hline
\end{tabular}

The testing process is to turn on lamp 1 or the red light, the command performed is 1 on, Nodemcu will send a hight command so that the Input Relay 1 (IN1) is active, the Vcc voltage source will flow through the relay and turn on lamp 1, while lamp 2 up to 3 stay off or die. This can be seen in Figure 9. in the next process the lights and relays will continue to live until the telegram command is returned by typing the syntax 1 off, and the light will turn off. The process of turning on and off the lights will be executed sequentially according to which command first.
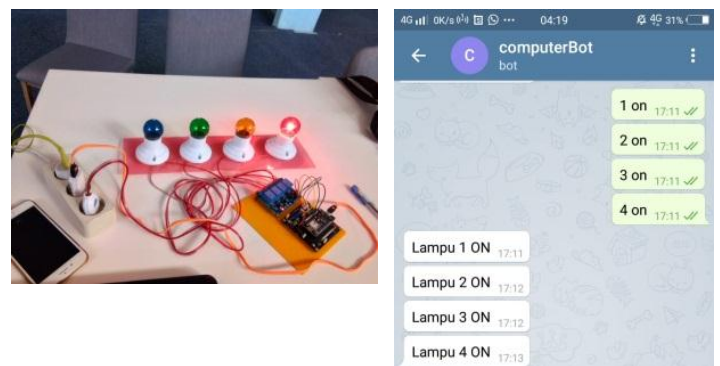

Figure 9. Process ON / OFF Lamp $1($ Red) and Telegram Commands

The commands on the telegram and feedback can be seen in Figure 9 when processing commands typed on the telegram application text page, telegram bots will respond to any commands made by the command command according to Table 2 .

\section{Delay Telegram App}

In the control process carried out by the telegram application to turn the lights on and off, the delay or delay time is obtained when typing commands, the response from the Telegram Bot is due to the influence of the speed of the wifi network connection or Wifi Hotspot, as seen in figure 10. 


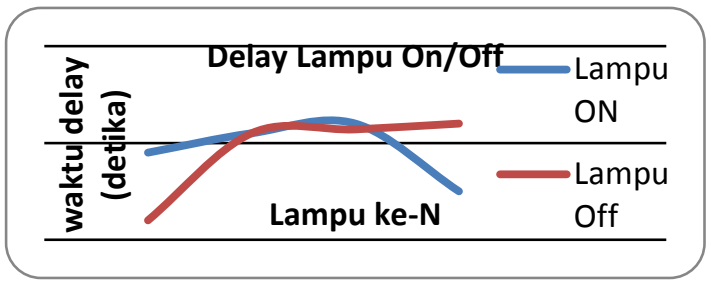

Figure 10. Delay Telegram App

The testing process to control lights 1 through 4 is done twice as a process, on the telegram page the difference in time between sending a command message, with a response reply from the telegram bot, in testing 1 , control light 1 when sending at 22.09 and getting a telegram bot response at 10:10 p.m., there is a difference of 45 seconds. On testing the 2nd lamp, the sending time is 22.10 , the reply from the telegram response is 22.11, there is a difference of 45 seconds. The testing process to turn on 4 lights is obtained by a difference of 25 seconds, and turning on lamp 3 is as long as 60 seconds delay.

The next testing process is to turn off the lights that have been turned on, here the lights cannot be turned off in parallel or at once, but gradually one after another. The process of turning off light 1 is the fastest, only requires 10 seconds delay, while the longest time is obtained when turning off light 4 , a delay time of 60 seconds. This can be seen in Table 4.3. all the above testing processes are carried out indoors or indoors, network connectivity greatly affects the speed or slow process of turning on and off lights.

\section{CONCLUSION}

From the description of the theory and testing that has been done, we can draw a number of conclusions:

1. This tool works in accordance with its function, namely as a light controller using the Telegram application as its collector, by using smartphone.

2. Wireless communication through the NodeMCu V3 module, working properly requires a stable internet network.

3. In the Control Process turn on and turn off the command lights or commands must be in accordance with the commands that exist in the Arduino Ide program.

4. There is delay between the process of turning on the lights (lights on) with feedback from the telegram bot. The delay process between turning off and turning ranges from 5 seconds to 60 seconds all depends on the WIFI network connection and the state of the process of sending commands.
5. The command or command to turn on or turn off the light will execute the relay to activate the voltage on the Lamp control circuit. Each command typed in the Telegram will be executed sequentially.

\section{ACKNOWLEDGMENT}

Some of the additions needed to improve the capabilities of this tool are:

1. Future research is expected to control the lamp with several Telegram IDs, and program execution can turn off lights at once.

2. Using Telegram can not only control the light device, but also other electronic devices on different networks.

\section{REFERENCES}

[1] Codepolitan edisi 19 maret 2016 Magazine. Invasi Internet Of things ditanah air. Diakses melalui https://www.codepolitan.com. Pada tanggal 25 maret 2018.

[2] Dhenny, R \& Dkk (2017). Sistem Pemantau \& Pengendalian Rumah Cerdas Menggunakan Infrastruktur Internet Messaging. Journal Link Vol 26/NO.1 .ISSN 1858-4667

[3] Ellian A, \& dkk (2016). Pengontrolan Lampu Melalui Internet menggunakan mikrokontroller Arduino Berbasis Android. Jurnal Transient, Vol 5, No.3. ISSN 2302-992

[4] F. Dwi, \& dkk,(2015) "Alat Kendali Lampu rumah menggunakan Bluethoot berbasi Android" Teknik Informatika STIMIK PalComTech

[5] https://infokomputer.grid.id/2017/03/fitur/mengenal-internetof-things-definisi-iot-manfaat-tantangan/ di akses pada tanggal 01 April 2017.

[6] Muzawi, R \& et al. 2018. Prototype Pengendali Lampu Jarak Jauh Dengan Jaringan internet berbasis Internet of things (IOT) Mengunakan Raspberry Pi 3, Vol 3 No 1, Jurnal Ilmiah Teknologi Informasi dan komunikasi. ISSN 2502-3470. 